\title{
25 GUERRILLA MARKETING IN CHILD INJURY PREVENTION-WINNING THE WAR TO KEEP KIDS SAFE IN NEW ZEALAND
}

doi:10.1136/injuryprev-2012-040590d.25

A Rola. Safekids New Zealand, New Zealand.

Background Unintentional childhood injury is a serious but neglected public health issue in New Zealand. The casualties are high (two children killed every week and 8184 children hospitalised every year), and the economic burden is immense-it cost the government NZ\$146.6 million in child injury claims during the 2007/ 2008 financial year.

Unintentional childhood injury is not seen as a priority issue, has few allies, and receives little support or recognition. The injury prevention workforce is facing an uphill battle, and Safekids, the child injury prevention service for New Zealand, is forced to pursue conventional goals with unconventional methods-using Guerrilla Marketing tactics. And somehow, Safekids New Zealand is winning the war.

Aims/Objectives/Purpose The purpose of this study it to present Guerrilla Marketing as an effective public health tool when funding or resources are limited or non-existent. It presents tactics used during the Safekids Campaigns of 2009-2011 (Child Passenger and Driveway Runover Injury)

Methods Safekids travels across the country to establish a network of coalitions to fight for child injury prevention. Safekids 'arms' communities with information and tools that encourage low-cost, innovative means to promote Safekids messages.

Results/Outcome Guerrilla Marketing played an important role during the 2009-2011 Safekids Campaigns, raising national awareness on unintentional child injury issues, moved the Government to consider law change, and empowered injury prevention workers across the country. 